\title{
POSTGRADUATE THESES WRITTEN ON DIGITAL STORYTELLING IN TURKEY: A CONTENT AND CITATION ANALYSIS
}

\author{
Beytullah Karagöz \\ Tokat Gaziosmanpaşa University, \\ Turkey
}

\begin{abstract}
:
The aim of this research is to examine postgraduate theses carried out on digital story in the field of education in Turkey with content and citation analysis. Methodological evaluation and citation analysis techniques were used in the research. In the research, 68 postgraduate theses accessed on the National Thesis Centre of the Council of Higher Education, a search platform, were examined. The findings of the research reveal that the number of theses on digital stories has increased until 2020. Most of the theses were prepared at Gazi University. Postgraduate theses were mainly carried out under the guidance of advisors with the title Associate Professor. The theses on digital stories were mostly prepared in the field of Elementary Education. Mixed approach models were mostly preferred as a method in theses. The sampling of the theses mostly consisted of students at K-12 level. Scale, achievement test, and interview form were used as data collection tools. The data were analyzed mostly using the t-test and content analysis. Digital stories were most frequently prepared by using Photo Story 3 and Movie Maker programs. Digital storytelling applications were mostly used with elementary and secondary school students. "Digital story/ (storytelling) narration/design", "academic achievement and "attitude" were the most frequently used keywords. The most cited type of source in the theses examined was articles. The most frequently cited source in the theses was the Computer $\mathcal{E}$ Education. Among the references to the books, Joe Lambert's Digital storytelling cookbook and traveling companion is at the top of the list. In addition, the most frequently cited researcher was Bernard R. Robin.
\end{abstract}

Keywords: citation analysis, digital story, content analysis, postgraduate thesis

\section{Introduction}

Storytelling, which has been continuing since ancient times, has paved the way for the emergence of the concept of digital story by reconsidering the storytelling according to

${ }^{i}$ Correspondence: email beytullah.karagoz@gop.edu.tr, beykara43@gmail.com 
the technological developments today. Digital storytelling emerged when Joe Lambert and Dana Atchley founded the Centre for Digital Storytelling at University of California, Berkeley in 1994 as a community arts centre for new media and this practice was based on the premise that everyone has a story to tell (Sylvester \& Greenidge, 2009). The Educational Uses of Digital Storytelling website was created at the University of Houston in 2004 under the leadership of Bernand Robin with the intention of serving as a useful resource for educators and students who are interested in how to integrate digital storytelling into various educational activities (Robin, 2008; Robin, 2020; Şeref, 2020b). In other words, it is possible to say that digital storytelling has been popular out-of-school environments for decades and has gained popularity and recognition in the field of education in recent years (Sylvester \& Greenidge, 2009).

So, what is digital storytelling, that has become widespread in the field of education? Many definitions of this concept have been made. According to Castañeda (2013, p. 45), digital storytelling is "the practice of combining multiple modes of technology, such as photography, text, music, audio narration, and video clips, to produce a compelling, emotional and in-depth story". According to Miller (2019, p. 3), "digital storytelling is a narrative entertainment that reaches its audience through digital technology and media". Kengürü (2016, p. 35) describes digital story as "a type of narrative that allows basically computer users to become creative storytellers or producers by choosing their own topics, carrying out research, writing a script, and developing an interesting story". Generally, the definition of digital storytelling revolves around the idea of "combining art of telling stories with various types of digital multimedia including pictures, recorded audio narration, and video" (Robin, 2006, p. 709).

Miller (2019, p. 4) stated that "the biggest difference between traditional narrative genres and digital storytelling is that the content of traditional narratives comes to us in an analogue form, while the content in digital storytelling comes to us in a digitalized form". A digital story is conveyed in the form of a personal narrative presented as a short film using a series of images, first-person audio narration, and sometimes a piece of music (Lambert, 2007). Lundby (2008, p. 1) emphasizes that digital stories have some characteristics such as a few minutes long, using inexpensive equipment and techniques, and centered on the narrator's own personal life in and told in his own voice.

Various classifications have been made about the types of digital stories. Robin (2006, p. 710) classified digital stories into three groups as “1) personal narratives - stories containing account of important events in one's life; 2) historical documentaries - stories that examine dramatic events that help us understand the past, and 3) stories designed to inform or guide the audience about a particular concept or practice". Gregori-Signes \& Pennock-Speck (2012) suggested different social and educational groups for simplification. Garrety (2008) grouped digital stories into five different categories including traditional stories, didactic stories, project-based stories, social justice and cultural stories, and reflective practice-based stories

The Centre for Digital Storytelling (2004) developed and disseminated the Seven Elements of Digital Storytelling. These seven elements are explained as follow: 1. Point 
of view (what is the main point of the story and what is the perspective of the author?), 2. A dramatic question (a key question that draws the attention of the viewer and will be answered at the end of the story), 3. Emotional content (serious issues that come alive in a personal and powerful way and connects the story to the audience), 4 . The gift of your voice (a way to personalize the story to help the audience understand the context), 5 . The power of the soundtrack (music or other sounds that support and embellish the storyline), 6. Economy (using just enough content to tell the story without overloading the viewer), 7. Pacing (the rhythm of the story and how slowly or quickly it progresses). Robin and Pierson (2008, p. 710) listed the expanded and modified digital storytelling elements as follows: 1 . the overall purpose of the story, 2 . the pace of the narrative, 3 . the perspective of the narrator, 4 . the use of a meaningful soundtrack, 5. dramatic question or questions, 6. the quality of the images, 7. selection of content 8. economy of story details, 9. sound clarity, 10. good grammar and use of language. The integrity of digital stories can be achieved with the use of these elements together.

Since digital storytelling aims to create a product, a certain process must be followed. Jakes \& Brennan (2005) divided this process into six phases: 1. Writing, 2. Developing a Scenario, 3. Creating a Storyboard, 4. Finding Sources, 5. Creating, 6. Sharing. In addition, Robin (2016, p. 23-24) compiled a 12-step process that students can follow in digital storytelling. This process includes the following stages: 1 . Choose a topic, 2. Do research on the topic, 3. Write a first draft of the story script, 4 . Receive feedback on the script, 5. Revise the script, 6. Find, create and add images, 7. Respect copyrights, 8. Create a storyboard, 9. Record audio narration, 10. Add background music (optional), 11. Build the digital story, 12. Publish the digital story.

\section{Literature Review}

It is reported that using digital storytelling in the field of education is generally a powerful learning approach (Wu \& Chen, 2020). According to Barrett (2006), digital storytelling promotes the convergence of student-centred learning strategies including student participation, reflection for deep learning, project-based learning, and integration of technology into instruction. Yüksel, Robin \& McNeil (2011) state that digital storytelling supports students' understanding of subject area knowledge, overall academic performance, technical presentation, writing, and research skills. Robin (2008) reports that students who can create digital stories gain digital literacy, global literacy, technology literacy and information literacy. Özkaya (2020) determined in meta-analysis that digital stories have a high effect on the development of Turkish language skills. Akgün \& Akgün (2020) report that the overall effect size of digital stories on academic achievement is strong. As can be seen, the use of digital stories in the field of education responds to the academic and techno-pedagogical needs of students in various fields.

This study is considered important in terms of presenting the status of the study area to the reader by examining the postgraduate theses on digital stories prepared in Turkey in terms of content and citation analysis, monitoring the study area by using 
different analysis metrics and shedding light on its intellectual appearance. Thus, young researchers and experienced academics who want to work in the field will have the opportunity to see holistically what and how it was discussed before.

The aim of the research is to examine the postgraduate theses about digital stories in Turkey in terms of content and citation. For this purpose, the study sought to answer the following research questions.

1) What are the overall characteristics (year and type, universities in which they are produced, supervisors' titles, subject area of the theses, most frequently used key words)?

2) What are the methodological characteristics (methods used, models, sample types, data collection tools, types of data analysis, digital storytelling tools, target population of the digital storytelling applications) of the theses examined?

3) What is the distribution of the sources cited in the theses examined according to their types?

4) What are the most cited journals in the theses examined?

5) What are the most cited books in the theses examined?

6) Who are the most cited researchers in the theses examined?

\section{Material and Methods}

The first dimension of the research was modelled as a methodological evaluation research. In the methodological evaluation, which is identified as "analytical evaluation of published materials", the reader is informed about the summary of the literature on the subject and the gaps and contradictions in the field are presented (Turan, Karadağ, Bektaş \& Yalçın, 2014). In the second part of the study, the citation analysis technique was used (Becker \& Chiware, 2015). Citation analysis is a type of analysis that helps researchers to know the sources that have a great leading role and importance in that field. Sources, journals, and authors that have a decisive role in the literature related to this analysis can be determined (Karagöz \& Şeref, 2020).

\subsection{Collection of Research Data}

The postgraduate theses, which constitute the source of the data of the research, were accessed from the website of the National Thesis Centre of the Council of Higher Education (https://tez.yok.gov.tr/UlusalTezMerkezi/). With the intention of accessing these theses, the "advanced search" tab was selected from the search section of the mentioned search platform on April 1, 2021. Scanning was carried out by selecting "all" in the "search box" section with the keywords "digital storytelling, digital story" separately in the search. The search was always carried out without year range limitation. PRISMA (Preferred Reporting Items for Systematic Reviews and Meta-Analyses) was used as a basis for the collection and analysis of data (Moher, et al., 2009). The diagram of the data collection process was given below (Figure 1): 
Identification of studies via databases and registers

Theses accessed through search on The Council of Higher

Education (YÖK)National

Thesis Centre YÖK $(\mathrm{n}=$ Theses accessed through 79)
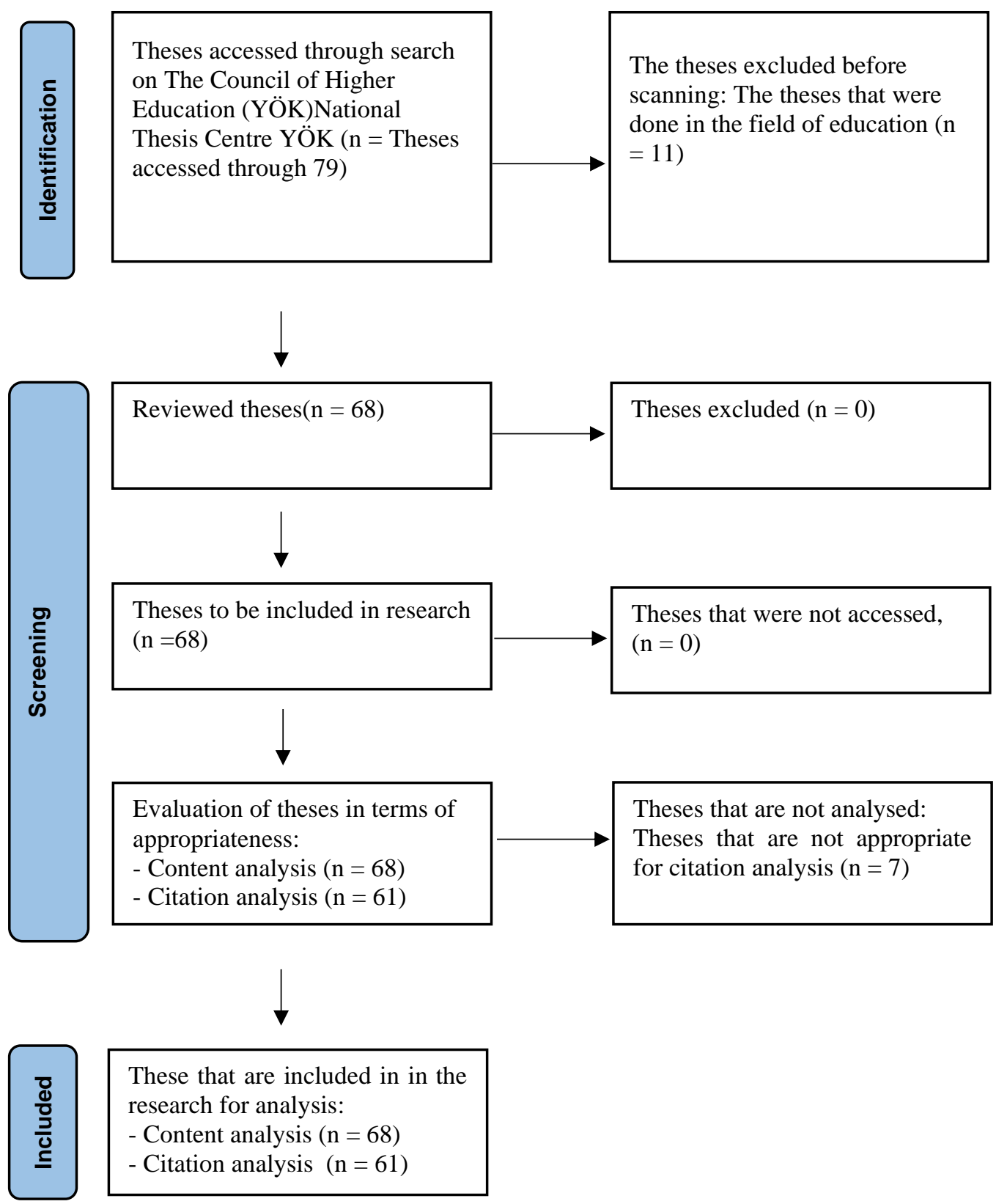

Figure 1: PRISMA Diagram

\subsection{Data Analysis}

68 postgraduate theses were exposed to content analysis after the data collection; 61 postgraduate theses were included in the citation analysis. The information in these theses was imported into the Microsoft Excel program and analyzed by the researcher. Thus, the content features of the theses were grouped. In the next stage, the sources used in the theses were transferred to the Excel file in columns. After this process, data analysis was completed through the Excel file created. 
It is stated that it is important for the researcher to be unbiased and objective when approaching the subject, to report the data elaborately, and to explain how the results are reached in order to ensure validity and reliability in research (Yıldırım \& Şimşek, 2011). An attempt was made to give detailed information about the process of accessing, compiling, and processing the data in order to ensure the validity and reliability of the research. The aim was to allow a second examination by keeping a record of the theses examined and the Excel file in which the raw data obtained from these theses were transferred. In the findings section, the data are presented directly in tables. The names of the journals, books, and authors were checked from international academic search engines (Google Scholar) and databases (Web of Science, Scopus, EBSCO, ProQuest, Semantic Scholar) and processed into the data set. The data processed into the data set were checked again two weeks later by the researcher in order not to cause possible errors due to the researcher.

\section{Findings}

This section included the findings related to the distribution of theses by type and year, universities, supervisor titles, disciplines, methods and models, sample type, data collection tools, type of data analysis, the tools used, target population, keywords, the types of sources cited, the most cited journals, books, and authors. Table 1 shows the distribution of theses by year and type.

\subsection{Content Analysis}

The findings obtained by examining 46 master's and 22 doctoral dissertations included in the content analysis are given in this section. The distribution of the theses according to their types and years is given in Table 1 below.

Table 1: The years and types of theses

\begin{tabular}{lccc}
\hline Year & Master's Theses & Doctoral Dissertations & Total \\
\hline 2011 & - & 1 & 1 \\
2012 & - & - & - \\
2013 & - & 1 & 2 \\
2014 & 4 & 1 & 5 \\
2015 & 1 & 4 & 5 \\
2016 & 2 & 3 & 5 \\
2017 & 5 & 2 & 7 \\
2018 & 6 & 3 & 9 \\
2019 & 20 & 3 & 23 \\
2020 & 8 & 4 & 12 \\
\hline Total & 46 & 22 & 68 \\
\hline
\end{tabular}

When Table 1 is examined, it is revealed that 1 doctoral dissertation in 2011, 1 doctoral dissertation in 2013, 4 master's theses in 2014 and 1 doctoral dissertation, 1 master's thesis and 4 doctoral dissertations in 2015, 2 master's theses and 3 doctoral dissertations in 2016, 
5 master's theses and 2 doctoral dissertations in 2017, 6 master's theses and 3 doctoral dissertations in 2018, 20 master's theses and 3 doctoral dissertations in 2019, and 8 master's theses and 4 doctoral dissertations in 2020 were written about digital storytelling in the field of education. A total of 46 master's theses and 22 doctoral dissertations were produced about the subject between 2011 and 2020 .

In addition, the distribution by years is given in the chart below in order to clearly monitor the change on a yearly basis.

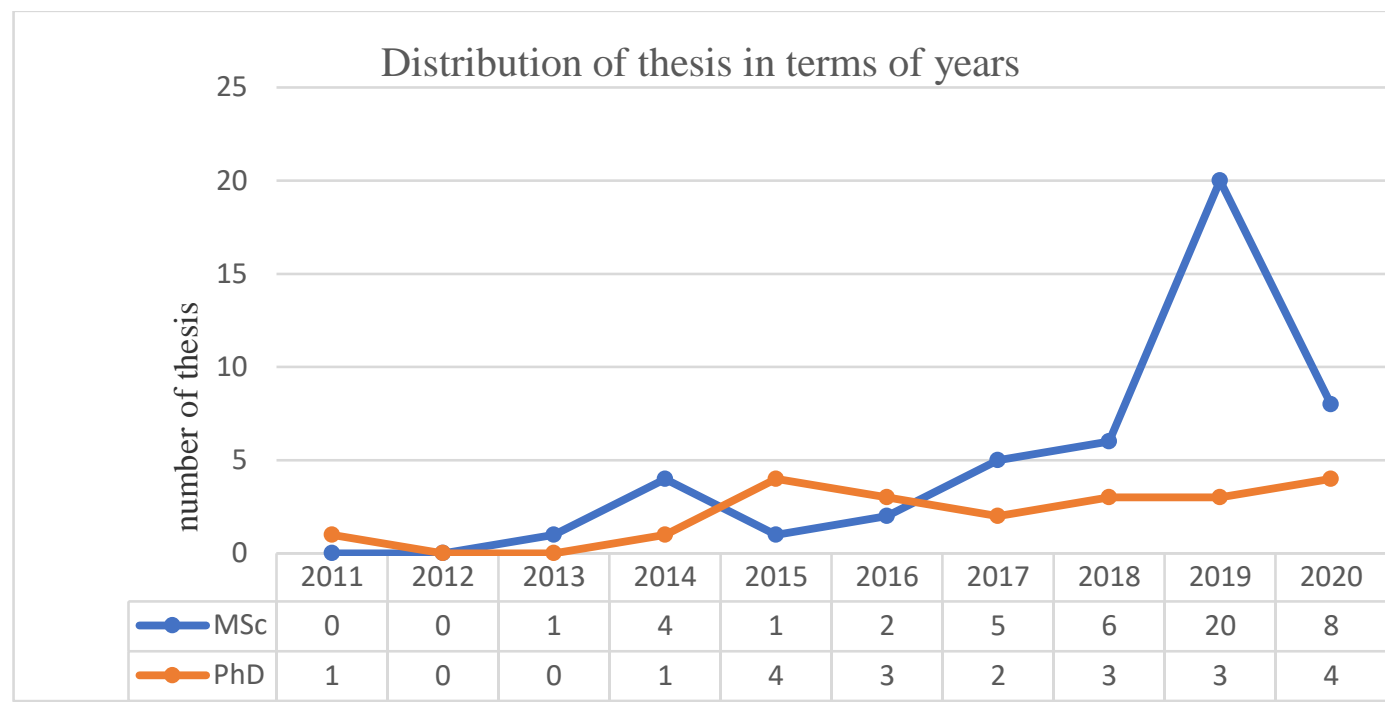

Figure 2: Distribution of theses in terms of year and type

The distribution of the theses examined according to the universities where they were completed is presented in Table 2.

Table 2: Universities where the theses were completed

\begin{tabular}{lccc}
\hline Universities & Master's Theses & Doctoral Dissertations & Total \\
\hline Gazi University & 3 & 3 & 6 \\
Atatürk University & 2 & 2 & 4 \\
Anadolu University & 1 & 2 & 3 \\
Erciyes University & 2 & 1 & 3 \\
Hacettepe University & 2 & 1 & 3 \\
METU & - & 3 & 3 \\
Mersin University & 2 & 1 & 3 \\
Muğla Sitkı Koçman University & 3 & - & 3 \\
Recep Tayyip Erdoğan University & 3 & - & 3 \\
Abantİzzet Baysal University & 2 & - & 2 \\
Bahçeşehir University & 2 & - & 2 \\
Balıkesir University & 1 & 1 & 2 \\
Dokuz Eylül University & 1 & 1 & 2 \\
Inönü University & 1 & 1 & 2 \\
Kastamonu University & 2 & - & 2 \\
Uludağ University & - & 2 & 2 \\
Uşak University & 1 & 1 & 2 \\
Adnan Menderes University & 1 & - & 1
\end{tabular}




\begin{tabular}{lccc}
\hline Afyon Kocatepe University & 1 & - & 1 \\
Akdeniz University & 1 & - & 1 \\
Aksaray University & 1 & - & 1 \\
Amasya University & 1 & - & 1 \\
Burdur Mehmet Akif Ersoy University & - & 1 & 1 \\
Çağ University & 1 & - & 1 \\
Çanakkale Onsekiz Mart University & 1 & - & 1 \\
Çukurova University & 1 & - & 1 \\
Eskişehir Osmangazi University & 1 & - & 1 \\
Firat University & 1 & - & 1 \\
Gaziantep University & 1 & - & 1 \\
Hatay Mustafa Kemal University & 1 & - & 1 \\
İhsan Doğramaci Bilkent University & 1 & - & 1 \\
Kirşehir Ahi Evran University & 1 & - & 1 \\
Kütahya Dumlupinar University & 1 & - & 1 \\
Manisa Celal Bayar University & 1 & - & 1 \\
Nevşehir University & 1 & - & 1 \\
Ondokuz Mayıs University & - & 1 & 1 \\
Sakarya University & - & 1 & 1 \\
Sivas Cumhuriyet University & 1 & - & 56 \\
\hline Total & 49 & 7 & 1 \\
\hline
\end{tabular}

When Table 2 is examined, it is found that the theses on digital storytelling were mostly prepared at Gazi University (6) and Atatürk University (4). In addition, it is possible to say that a thesis on digital story has been produced in 39 different universities.

The distribution of the theses examined according to the supervisors' titles is given in Table 3.

Table 3: Distribution of Postgraduate Theses in terms of Supervisors' Titles

\begin{tabular}{lccc}
\hline Year & Dr. (Assistant Professor) & Assoc. Prof. Dr & Prof. Dr \\
\hline Master's Thesis & 17 & 22 & 7 \\
Doctoral Dissertation & - & 8 & 14 \\
\hline Total & 17 & 30 & 21 \\
\hline
\end{tabular}

When Table 3 is examined, 17 of the supervisors of the master's theses are doctors (assistant professors), 22 associate professors and 7 professors and considering doctoral dissertations, 8 of the supervisors have the title of associate professor and 14 of them have the title of professor. In total, it was determined that 17 of the supervisors were doctors (assistant professors), 30 associate professors, and 21 professors.

The distribution of the theses examined according to the subject areas in which they were prepared is given in Table 4 . 


\begin{tabular}{lccc}
\hline \multicolumn{4}{c}{ Table 4: Subject areas of the theses } \\
\hline Discipline & Master's Theses & Doctoral Dissertations & Total \\
\hline German Language Teaching & 1 & - & 1 \\
Computer and Instructional Technologies & 6 & 5 & 11 \\
Teaching & & & \\
Educational Sciences (Educational Technologies) & 2 & - & 2 \\
Educational Sciences (Program) & 2 & 1 & 3 \\
Science Education & 7 & - & 7 \\
Physics Education & - & 1 & 1 \\
Fine Arts (Art) Education & - & 1 & 1 \\
Elementary Mathematics Education & 1 & 1 & 2 \\
English Language Teaching & 4 & 1 & 5 \\
Preschool Education & 3 & 1 & 4 \\
Special Education (Mental) & 1 & - & 1 \\
Elementary Education & 12 & 5 & 17 \\
Social Studies & 3 & 1 & 4 \\
Turkish Education & 3 & 3 & 6 \\
Teaching Turkish as a Foreign Language & 1 & 2 & 3 \\
\hline Total & 46 & 22 & 68 \\
\hline
\end{tabular}

When Table 4 is examined, it is found that the theses on digital stories are mostly prepared in the fields of Elementary Education (17) and Computer and Instructional Technologies Education (11). These areas are followed by Science Education (7) and Turkish Education (6).

The distribution of the theses examined according to their methods is presented in Table 5 below.

Table 5: Distribution of Postgraduate Theses in terms of Research Design

\begin{tabular}{lccc}
\hline Method & Master's Theses & Doctoral Dissertations & Total \\
\hline Qualitative & 9 & 7 & 16 \\
Quantitative & 22 & 2 & 24 \\
Mixed & 14 & 13 & 27 \\
Unspecified & 1 & - & 1 \\
\hline Total & 46 & 22 & 68 \\
\hline
\end{tabular}

When Table 5 is examined, it is revealed that 9 master's theses and 7 doctoral dissertations are designed with a qualitative approach and 22 master's theses and 2 doctoral dissertations were designed with a quantitative approach, and 14 master's theses and 13 doctoral dissertations were designed with a mixed approach. In addition, it is found that there is 1 master's thesis with an unspecified research method.

The examination of the theses according to the model used is given in Table 6. 


\begin{tabular}{lccc}
\hline \multicolumn{4}{c}{ Table 6: Designs (Models) } \\
\hline Design & $\begin{array}{c}\text { Master's } \\
\text { Theses }\end{array}$ & $\begin{array}{c}\text { Doctoral } \\
\text { Dissertations }\end{array}$ & Total \\
\hline Experimental & 22 & 2 & 24 \\
Case Study & 6 & 2 & 8 \\
Scanning & 1 & - & 1 \\
Meta-synthesis, narrative & - & 1 & 1 \\
Action Research & 3 & 3 & 6 \\
Phenomenology & - & 1 & 1 \\
Mixed (experimental,phenomenology) & - & 1 & 1 \\
Mixed (convergent parallel design) & 1 & 3 & 4 \\
Mixed (experimental, case) & - & 1 & 1 \\
Mixed (embedded experimental design) & 1 & 3 & 4 \\
Mixed (qualitative supported) & 1 & - & 1 \\
Mixed (unspecified) & 7 & 2 & 9 \\
Mixed (explanatory sequential design) & 2 & 1 & 3 \\
Mixed (aggregation/variation) & - & 1 & 1 \\
Mixed (concurrent nested mixed methods design) & 2 & 1 & 3 \\
\hline Total & 46 & 22 & 68 \\
\hline
\end{tabular}

When Table 6 is examined, it is reported that the following research designs were used with the following theses: experimental model with 24 theses, case studies with 8 of them and survey research with1 thesis, meta-synthesis research with 1 thesis, action research with 6 theses, phenomenology with 1 thesis, and mixed research designs with 27 theses. The examination of the theses according to the sample types is given in Table 7.

Table 7: Examination of Theses in term of Types of Sampling

\begin{tabular}{lccc}
\hline Sampling & Master's Theses & Doctoral Dissertations & Total \\
\hline K-12 Student & 39 & 14 & 53 \\
University Student & 5 & 3 & 8 \\
Foreign Adults & 1 & 2 & 3 \\
Document and field experts & - & 1 & 1 \\
University students and elementary school & - & 1 & 1 \\
students & & & \\
Teacher & - & 1 & 1 \\
Elderly & 1 & - & 1 \\
\hline Total & 46 & 22 & 68 \\
\hline
\end{tabular}

When Table 7 is examined, it is found that the types of sampling used in the theses are as follows: K-12 students in 53 theses, university students in 8 theses, foreign adults in 3 theses, document and field experts in 1 thesis, university students and secondary school students in 1 thesis, teachers in 1 thesis, and elderly people in 1 thesis. The reason why mostly K-12 students are preferred as the sampling, and why it is a normal situation is that digital stories are applied on students at this level. Information on data collection tools is presented in Table 8 below. 


\begin{tabular}{lcc}
\hline \multicolumn{3}{c}{ Table 8: Data Collection Tools } \\
\hline Tools & Master's Theses & Doctoral Dissertations \\
\hline Scale & 29 & 16 \\
Achievement test & 23 & 9 \\
Interview form & 17 & 15 \\
Rubric & 8 & 7 \\
Observation form & 4 & 9 \\
Diary & 4 & 8 \\
Questionnaire & 6 & 2 \\
Document & 3 & 1 \\
\hline Total & 94 & 67 \\
\hline
\end{tabular}

When Table 8 is examined, it is revealed that types of data collection tools that are mostly used are scale (45), achievement test (32), and interview form (32). Scales are data collection tools which are frequently used in the studies measuring affective domains such as attitude, anxiety, and motivation. Here, affective concepts such as anxiety, attitude, motivation, and self-efficacy are used in keywords. In this context, the frequency of keyword usage monitored can be explained with this relationship. Types of data analyses used in the theses are presented in Table 9.

Table9: Types of Data Analysis

\begin{tabular}{lcc}
\hline Types of Analysis & Master's Theses & Doctoral Dissertations \\
\hline Descriptive Analysis & 10 & 2 \\
Kruskall Wallis-H & 2 & - \\
Mann Whitney U & 14 & 8 \\
t-test & 27 & 9 \\
Descriptive quantitative statistics & 12 & 3 \\
ANOVA & 3 & 4 \\
Content analysis & 11 & 15 \\
Ancova & 4 & 2 \\
Wilcoxon & 12 & 6 \\
Regression & - & 1 \\
\hline Total & 95 & 50 \\
\hline
\end{tabular}

When Table 9 is examined, it is found that t-test (36), content analysis (26), Mann Whitney $\mathrm{U}$ (22), and Wilcoxon (18) techniques are mostly used for data analysis. It can be stated that the frequent use of the $t$-test is to compare the scores between the groups in experimental studies. The high use of content analysis may be related to the in-depth examination of the data obtained through qualitative methods in studies conducted using qualitative and mixed models. The digital storytelling tools used in the theses are presented in Table 10. 


\begin{tabular}{|c|c|c|c|}
\hline \multicolumn{4}{|c|}{ Table 9: Names of the Tools Used } \\
\hline Name of the Tool & $\begin{array}{l}\text { Master's } \\
\text { Theses }\end{array}$ & $\begin{array}{c}\text { Doctoral } \\
\text { Dissertations }\end{array}$ & Total \\
\hline A study that does not require a tool & - & 1 & 1 \\
\hline A web or software program not used & 2 & 2 & 4 \\
\hline Ready digital storytelling (Eba, Morpa Publishing) & 9 & - & 9 \\
\hline WeVideo Web 2.0 & - & 2 & 2 \\
\hline Photo Story 3 & 12 & 5 & 17 \\
\hline Windows Movie Maker & 6 & 3 & 9 \\
\hline Power Point & 3 & 1 & 4 \\
\hline Photo Story 3 and Movie Maker & 1 & 2 & 3 \\
\hline iMovie and Movie Maker & - & 1 & 1 \\
\hline Adobe Photoshop, Adobe Flash Player, Adobe & - & 1 & 1 \\
\hline \multicolumn{4}{|l|}{ Premiere } \\
\hline AdobePhotoshop and Movie Maker & 1 & - & 1 \\
\hline Photo Story, Movie Maker, Animoto & - & 1 & 1 \\
\hline GoAnimate for School Web 2.0 & - & 1 & 1 \\
\hline iMovie & 1 & - & 1 \\
\hline Animaker Web 2.0 & 1 & - & 1 \\
\hline Storyboardthat Web 2.0 & 1 & - & 1 \\
\hline Adobe Photoshop, Illustrator, Sony Vegas Pro & 1 & - & 1 \\
\hline StoryJumper Web 2.0 & 1 & - & 1 \\
\hline Scratch & 1 & 1 & 2 \\
\hline Powtoon Web 2.0 & 2 & - & 2 \\
\hline Adobe Illustrator and AdobeAfterEffects & 1 & - & 1 \\
\hline Windows Photos & 1 & - & 1 \\
\hline Photo Story 3 and Powerpoint & 1 & - & 1 \\
\hline Toontastic 3D & 1 & - & 1 \\
\hline $\begin{array}{l}\text { Photo Story 3, Movie Maker, Microsoft PowerPoint, } \\
\text { iMovie and Platagon }\end{array}$ & - & 1 & 1 \\
\hline Total & 46 & 22 & 68 \\
\hline
\end{tabular}

Table 10 presents the programs and web 2.0 tools used in research to create digital stories. Accordingly, Photo Story 3 (17), Windows Movie Maker (9), and Power Point (4) were the most used applications in the studies. In addition, templates ready for digital stories were preferred in 9 studies. In 4 studies, any program or web 2.0 tool was used. In addition to these, it is possible to see that new generation web 2.0 tools such as Powtoon, GoAnimate, StoryJumper, Storyboard that were preferred in some studies.

The target population who are exposed to digital storytelling practices in the theses examined are presented in Table 11.

Table 11: Target population with whom digital storytelling practices is carried out

\begin{tabular}{lccc}
\hline Target population & Master's Theses & Doctoral Dissertations & Total \\
\hline Secondary & 18 & 7 & 25 \\
Elementary & 15 & 5 & 20 \\
University & 5 & 3 & 8 \\
High School & 3 & 2 & 5 \\
Pre-school & 3 & - & 3
\end{tabular}




\begin{tabular}{lccc}
\hline Foreigners living in Turkey (adults) & 1 & 2 & 3 \\
Old people & 1 & - & 1 \\
Teacher & - & 1 & 1 \\
University and secondary school students & - & 1 & 1 \\
Field expert opinion & - & 1 & 1 \\
\hline Total & 46 & 22 & 68 \\
\hline
\end{tabular}

In Table 11, the target population of digital storytelling practices in the studies are given. Accordingly, secondary school (25), primary school (20), university (8), and high school (5) students were mostly chosen as the target population in the studies. The reason why secondary school and primary school students are mainly chosen as the target population may be that digital storytelling practices are suitable for their age levels. The most frequently used key words in the theses examined are presented in Table 12.

Table 12: Most frequently used key words in the theses examined

\begin{tabular}{llll}
\hline Key Word & $f$ & Key Word & $f$ \\
\hline Digital story/storytelling narration/design & 65 & Writing skill & 2 \\
Academic achievement & 10 & Foreign language education & 2 \\
Attitude & 10 & Learning strategies & 2 \\
(Integration of) technology & 5 & Elementary & 2 \\
Listening skills & 5 & Vocabulary teaching & 2 \\
Science education/physical sciences & 5 & Retention & 2 \\
Social studies & 5 & Case study & 2 \\
Reading skills & 5 & Turkish education & 2 \\
Writing self-efficacy & 4 & Digital literacy \\
Values education & 4 & Action research & 2 \\
Pre-school education & 3 & 3rdgrade & 2 \\
21st-century skills & 3 & English as a foreign language & 2 \\
Writing anxiety & 3 & Comprehension \\
Turkish as a foreign language & 3 & Reading motivation & 2 \\
Motivation & 3 & Permanence & 2 \\
Creative writing & 3 & Gifted and talented students & 2 \\
\hline
\end{tabular}

Note: Similar keywords are grouped within themselves. Two or more key words that are used were presented.

In Table 12, the keywords (word groups) included in the theses are presented. Accordingly, the most repeated key words are digital story/storytelling narration/design (65), academic achievement (10), attitude (10), technology (integration) (5), listening skills (5), science education/science (5), social studies (5), and reading skills (5).

Below is presented the word cloud created with the key words. 


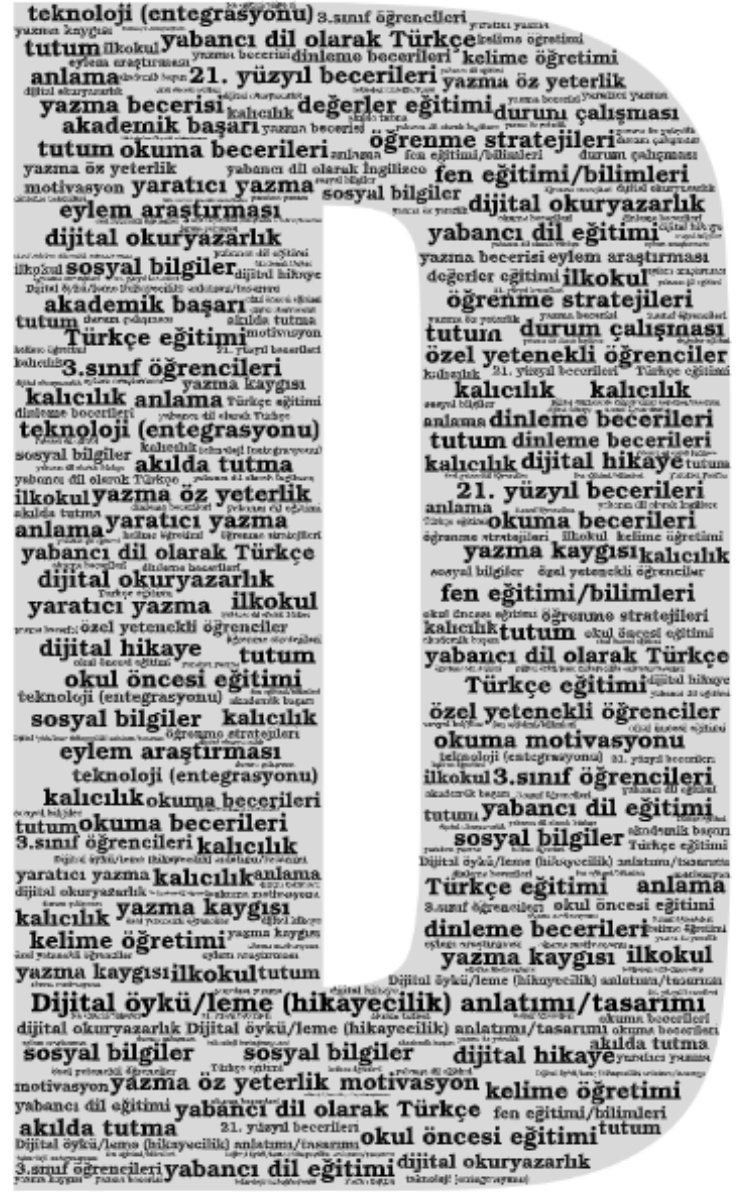

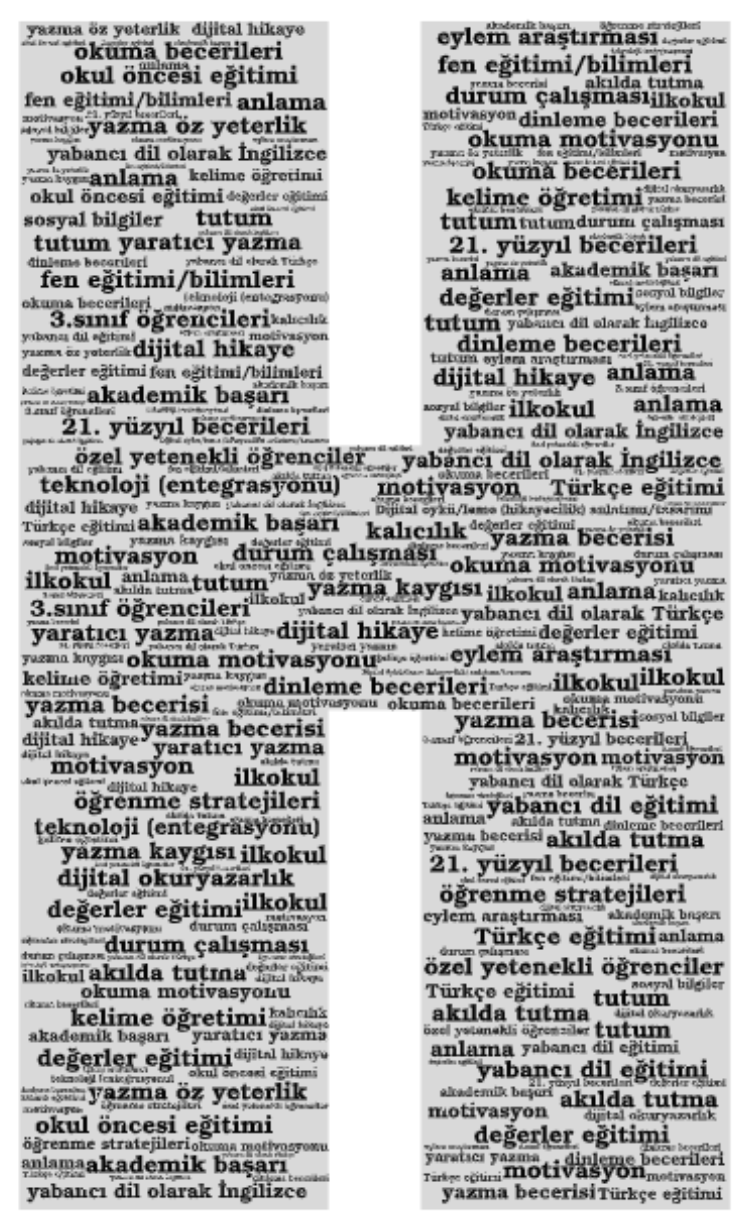

Figure 3: Word cloud created with the key words

\subsection{Citation Analysis}

The findings obtained by examining 41 master's theses and 20 doctoral dissertations included in the citation analysis are presented in this section. The distribution according to the types of sources cited in the theses is given below (Table 13).

Table 13: Distribution of citations in terms of types

\begin{tabular}{lcccccc}
\hline \multirow{2}{*}{$\begin{array}{l}\text { Type of } \\
\text { a cited publication }\end{array}$} & \multicolumn{2}{c}{ Master's Theses } & \multicolumn{2}{c}{ Doctoral Dissertations } & \multicolumn{2}{c}{ Total } \\
\cline { 2 - 7 } & $\mathbf{n}$ & $\mathbf{\%}$ & $\mathbf{n}$ & $\mathbf{\%}$ & $\mathbf{n}$ & $\mathbf{\%}$ \\
\hline Article & 2466 & 45.31 & 2484 & 50.03 & 4950 & 47.56 \\
Thesis & 1037 & 19.05 & 651 & 13.11 & 1688 & 16.21 \\
Book & 1363 & 25.04 & 1173 & 23.62 & 2536 & 24.36 \\
Paper & 263 & 4.83 & 369 & 7.43 & 632 & 6.07 \\
E-Source & 291 & 5.34 & 244 & 4.91 & 535 & 5.14 \\
Others & 22 & 0.4 & 44 & 0.88 & 66 & 0.63 \\
\hline Total & 5442 & 100 & 4965 & 100 & 10407 & 100 \\
\hline
\end{tabular}

Table 13 presents the distribution of the sources cited according to their types. Accordingly, in the master's theses, the articles (2466) were the most cited sources and then they were followed by the books (1363), theses (1037), e-sources (291), and papers 
(263), respectively. On the other hand, the sources included in the others (22) category were the least cited ones. In doctoral dissertations, the articles (2484) were the most cited sources again and then they were followed by the books (1173), theses (651), paper (369), and e-sources (244), respectively; however, the least cited sources were included in the others (44) category. When the postgraduate theses were evaluated together, it was determined that the most cited type of source was the articles (4950)and then came the books (2536), theses (1688), paper (632), and e-sources.

In Table 14, the journals/periodicals in which the articles in the theses are included are listed.

Table 14: Most frequently cited journals/periodicals in postgraduate theses

\begin{tabular}{|c|c|c|c|c|c|}
\hline Rank & $\begin{array}{c}\text { Journal/ } \\
\text { Periodical Name }\end{array}$ & Index & $\begin{array}{l}\text { Number } \\
\text { of Citation }\end{array}$ & $\begin{array}{c}\text { TR } \\
\text { Index Citation }\end{array}$ & $\begin{array}{l}\text { Impact } \\
\text { Factor }\end{array}$ \\
\hline 1 & Computers \&Education & SSCI & 59 & - & 5.296 \\
\hline 2 & $\begin{array}{l}\text { Educational Technology \& } \\
\text { Society }\end{array}$ & SSCI & 54 & - & 2.720 \\
\hline 3 & $\begin{array}{l}\text { Learning \& Leading with } \\
\text { Technology }\end{array}$ & Ended in 2014 & 38 & - & - \\
\hline 4 & $\begin{array}{l}\text { Journal of Research in } \\
\text { Education and Teaching }\end{array}$ & $\begin{array}{l}\text { Other Indexes } \\
\text { (RootIndexing, } \\
\text { arastirmax) }\end{array}$ & 38 & - & - \\
\hline 5 & $\begin{array}{l}\text { The Turkish Online } \\
\text { Journal of Educational } \\
\text { Technology }\end{array}$ & ERIC & 35 & - & - \\
\hline 6 & Theory Into Practice & SSCI & 31 & - & 1.978 \\
\hline 7 & Elementary Online & TR INDEX & 29 & 5288 & - \\
\hline 8 & $\begin{array}{l}\text { Turkish Online Journal of } \\
\text { Qualitative Inquiry }\end{array}$ & Scopus, TR INDEX & 28 & 186 & - \\
\hline 9 & Turkish Studies & TR INDEX & 26 & 11724 & - \\
\hline 10 & $\begin{array}{l}\text { Educational Technology } \\
\text { Theory and Practice }\end{array}$ & TR INDEX & 24 & 260 & - \\
\hline 11 & Digital Education Review & Scopus, ERIC & 21 & - & - \\
\hline 12 & Education and Science & SSCI & 20 & - & 0.757 \\
\hline 13 & $\begin{array}{l}\text { International Journal of } \\
\text { Research Studies in } \\
\text { Educational Technology }\end{array}$ & $\begin{array}{c}\text { Other Indexes } \\
\text { (Index Copernicus) }\end{array}$ & 20 & - & - \\
\hline
\end{tabular}

Note: SSCI(Social Science Citation Index), ERIC (Education Resources Information Centre), ESCI (Emerging Sources Citation Index), Procedia - Social and Behavioral Sciences were not included in the list as they were open access collection of conference papers published between 2009 and 2018 on basic social and behavioral sciences. The Journal of Learning \&Leading with Technology ceased its publication in 2014.

When Table 14 is examined, it is revealed that the first four journals cited in master's theses are Computers $\mathcal{E}$ Education (59), Educational Technology $\mathcal{E}$ Society (54),Learning ELeading with Technology (38), and Journal of Education and Education Research (38). The journals that are cited 20times and above are indexed by 4 SSCI, 2 by ERIC, 4 by TR INDEX, and 2 by other indexes. One of the journals ceased its publication. 7 of these journals are Turkey-addressed publications. 
Table 15 presents the most frequently cited books and book chapters in master's theses.

Table 15: Most frequently cited books in master's theses

\begin{tabular}{|c|c|c|c|}
\hline Rank & Book- Section in a Book & $\begin{array}{l}\text { Number of } \\
\text { Citations }\end{array}$ & $\begin{array}{c}\text { GS } \\
\text { Citation }\end{array}$ \\
\hline 1 & $\begin{array}{l}\text { Lambert, J. (2010). Digital storytelling cookbook and traveling } \\
\text { companion. Berkeley, CA: Digital Diner Press. }\end{array}$ & 31 & 144 \\
\hline 2 & $\begin{array}{l}\text { Ohler, J. (2008). Digital Storytelling in The Classroom: New } \\
\text { Media Pathways to Literacy, Learning and Creativity. Thous } \\
\text { and Oaks, CA: Corwin Press. }\end{array}$ & 28 & 896 \\
\hline 3 & $\begin{array}{l}\text { Büyüköztürk, Ş., KılıçÇakmak, E., Akgün, Ö. E., Karadeniz, } \\
\text { Ş.andDemirel, F. (2014). Scientific research methods. Ankara: } \\
\text { PegemAkademi. }\end{array}$ & 20 & 11165 \\
\hline 4 & $\begin{array}{l}\text { Lambert, J. (2013). Digital storytelling: Capturing lives, creating } \\
\text { community. Routledge: NewYork, NY. }\end{array}$ & 16 & 2084 \\
\hline 5 & $\begin{array}{l}\text { Yıldırım, A., and Şimşek H. (2013). Qualitative research } \\
\text { methods in social sciences. Ankara: SeçkinYayınları. }\end{array}$ & 16 & 24817 \\
\hline 6 & $\begin{array}{l}\text { Büyüköztürk, Ş. (2017). Handbook for data analysis in social } \\
\text { sciences. Ankara: Pegem. }\end{array}$ & 14 & 12468 \\
\hline 7 & $\begin{array}{l}\text { Alexander, B. (2011). The new digital storytelling: Creating } \\
\text { narratives with new media. Praegeri, Santa Barbara, CA. }\end{array}$ & 12 & 553 \\
\hline 8 & $\begin{array}{l}\text { Karasar, N. (2015). Scientific research methods. Ankara: Nobel } \\
\text { Yayıncilı. }\end{array}$ & 12 & 18213 \\
\hline 9 & $\begin{array}{l}\text { Fraenkel, J. R., Wallen, N. E., \&Hyun, H. H. (2012). How to } \\
\text { design and evaluate research in education (8th ed.). New York: } \\
\text { McGrawHill. }\end{array}$ & 9 & 28688 \\
\hline 10 & $\begin{array}{l}\text { Akyol, H. (2013). The first teaching of reading and writing } \\
\text { teaching in Turkish. Ankara: PegemAkademiYayıncillk. }\end{array}$ & 8 & 580 \\
\hline 11 & $\begin{array}{l}\text { Frazel, M. (2010). Digital storytelling: Guide for educators. } \\
\text { Washington: International Society for Technology in Education } \\
\text { Publications. }\end{array}$ & 8 & 164 \\
\hline 12 & $\begin{array}{l}\text { Miles, M. B., \& Huberman, A. M. (1994). Qualitative data } \\
\text { analysis: An expanded sourcebook (2nd ed.). Thousand Oaks, } \\
\text { CA: Sage. }\end{array}$ & 7 & 117379 \\
\hline 13 & $\begin{array}{l}\text { Matthews-De Natale, G. (2008). Digital Storytelling: Tips and } \\
\text { Resources. Boston: Simmons College. }\end{array}$ & 7 & 95 \\
\hline
\end{tabular}

When Table 15 is examined, it is found that the most cited books in the theses are called Digital Story Telling Cookbook and Traveling Companion (31), Digital Storytelling in the classroom: New media Pathways to Literacy, Learning, And Creativity (28), Scientific Research Methods (20), Digital Storytelling: Capturing Lives, Creating Community (16), and Qualitative Research Methods in Social Sciences (16).

Table 16 presents the most cited researchers in master's theses. 


\begin{tabular}{clcc}
\hline \multicolumn{5}{c}{ Table 16: Most frequently cited authors in master's thesis } \\
\hline Rank & Author & Number of Citations & GS Citation \\
\hline 1 & Bernard R. Robin & 128 & 5386 \\
2 & Joe Lambert & 49 & - \\
3 & Sara Kajder & 43 & 1653 \\
4 & ŞenerBüyüköztürk & 32 & 42962 \\
5 & Jason Ohler & 35 & - \\
6 & David S. Jakes & 35 & - \\
7 & Pelin Yüksel & 32 & 814 \\
8 & Bülent Doğan & 32 & 393 \\
9 & Ferit Karakoyun & 31 & 288 \\
10 & Ya-Tİng C. Yang & 31 & - \\
11 & Wan-Chi I. Wu & 30 & - \\
12 & Alaa Sadik & 28 & 1368 \\
13 & Veysel Demirer & 27 & 1115 \\
14 & Özcan Demirel & 26 & - \\
15 & Glen Bull & 26 & - \\
16 & Güler Göçen-Kabaran & 25 & 175 \\
17 & Helen Barrett & 25 & - \\
18 & Özkan Kahraman & & - \\
\hline
\end{tabular}

When Table 16 is examined, the top five most cited authors in master's theses are Bernard R. Robin (128), Joe Lambert (49), Sara Kajder (43), Şener Büyüköztürk (42), and Jason Ohler (37). Four of the top five authors have been carrying out digital storytellingoriented studies. Şener Büyüköztürk is known in the literature for his studies in the field of scientific research methods. In Table 17, the most cited journals in doctoral dissertations are listed.

Table 17: Most frequently cited journals/periodicals in doctoral dissertations

\begin{tabular}{|c|c|c|c|c|c|}
\hline Rank & Journal / Periodical Name & Index & $\begin{array}{c}\text { Number of } \\
\text { Citation }\end{array}$ & $\begin{array}{c}\text { TR } \\
\text { Index Citation }\end{array}$ & $\begin{array}{l}\text { Impact } \\
\text { Factor }\end{array}$ \\
\hline 1 & Computers \& Education & SSCI & 51 & - & 5.296 \\
\hline 2 & Educational Technology \& Society & SSCI & 40 & - & 2.720 \\
\hline 3 & $\begin{array}{l}\text { Learning \& Leading with } \\
\text { Technology }\end{array}$ & $\begin{array}{l}\text { ended in } \\
2014\end{array}$ & 36 & - & - \\
\hline 4 & Turkish Studies & $\begin{array}{c}\text { TR } \\
\text { INDEX }\end{array}$ & 34 & 11724 & \\
\hline 5 & The Reading Teacher & SSCI & 31 & - & 1.281 \\
\hline 6 & Digital Education Review & $\begin{array}{l}\text { ESCI- } \\
\text { ERIC }\end{array}$ & 31 & - & 1.119 \\
\hline 7 & Journal of Educational Psychology & SSCI & 27 & - & 6.133 \\
\hline 8 & $\begin{array}{l}\text { The Turkish Online Journal of } \\
\text { Educational Technology }\end{array}$ & ERIC & 23 & - & - \\
\hline 9 & Theory Into Practice & SSCI & 21 & - & 1.978 \\
\hline 10 & Elementary Online & TR ERIC & 20 & 5288 & \\
\hline 11 & Education and Science & SSCI & 15 & - & 0.757 \\
\hline 12 & $\begin{array}{l}\text { International Journal of Information } \\
\text { and Communication Technology } \\
\text { Education }\end{array}$ & Scopus & 14 & - & - \\
\hline
\end{tabular}




\begin{tabular}{llcccc}
\hline \hline 13 & $\begin{array}{l}\text { Hacettepe University Journal of } \\
\text { Education }\end{array}$ & TR & 14 & 8581 & - \\
\hline
\end{tabular}

When Table 17 is examined, Computers $\mathcal{E}$ Education (51), Educational Technology $\mathcal{E}$ Society (40), Learning $\mathcal{E}$ Leading with Technology (36), and Turkish Studies (34) are among the top four journals cited in doctoral dissertations. Of the 14 or above cited journals, 6 are indexed by SSCI, 2 by ERIC, 3 by TR Index, and 1 by Scopus. One of the journals ceased its publication. 5 of these journals are Turkey-addressed publications.

Table 18 presents the most frequently cited books and book chapters in master's theses.

Table 18: Most frequently cited books in doctoral dissertations

\begin{tabular}{|c|c|c|c|}
\hline Rank & Book- Section in a Book & $\begin{array}{l}\text { Number of } \\
\text { Citations }\end{array}$ & $\begin{array}{c}\text { GS } \\
\text { Citation } \\
\end{array}$ \\
\hline 1 & $\begin{array}{l}\text { Lambert, J. (2010). Digital storytelling cookbook and traveling } \\
\text { companion. Berkeley, CA: Digital Diner Press. }\end{array}$ & 17 & 144 \\
\hline 2 & $\begin{array}{l}\text { Ohler, J. (2008). Digital Storytelling in The Classroom: New Media } \\
\text { Pathways to Literacy, Learning and Creativity. Thousands Oaks, } \\
\text { CA: Corwin Press. }\end{array}$ & 16 & 896 \\
\hline 3 & $\begin{array}{l}\text { Lambert, J. (2013). Digital storytelling: Capturing lives, creating } \\
\text { community. Routledge: New York, NY. }\end{array}$ & 13 & 2084 \\
\hline 4 & $\begin{array}{l}\text { Yıldırım, A., and Şimşek H. (2013). Qualitative research methods } \\
\text { in social sciences. Ankara: SeçkinYayınları. }\end{array}$ & 13 & 24817 \\
\hline 5 & $\begin{array}{l}\text { Frazel, M. (2010). Digital storytelling: Guide for educators. } \\
\text { Washington: International Society for Technology in Education } \\
\text { Publications. }\end{array}$ & 11 & 164 \\
\hline 6 & $\begin{array}{l}\text { Miles, M. B., \& Huberman, A. M. (1994). Qualitative data analysis: } \\
\text { An expanded sourcebook (2nd ed.). Thousand Oaks, CA: Sage. }\end{array}$ & 11 & 117442 \\
\hline 7 & $\begin{array}{l}\text { Creswell, J. W. and Clark, P. L. V. (2007). Designing and } \\
\text { conducting mixed methods research. USA: Sage Publications Inc. }\end{array}$ & 11 & 42518 \\
\hline 8 & $\begin{array}{l}\text { Fraenkel, J. R., Wallen, N. E., \& Hyun, H. H. (2012). How to } \\
\text { design and evaluate research in education (8th ed.). New York: } \\
\text { McGrawHill. }\end{array}$ & 10 & 28723 \\
\hline 9 & $\begin{array}{l}\text { Creswell, J. W. (2012). Educational research: Planning, } \\
\text { conducting, and evaluating quantitative and qualitative research } \\
\text { (4th ed.). Boston: Pearson. }\end{array}$ & 9 & 56064 \\
\hline 10 & $\begin{array}{l}\text { Robin, B. (2008). The effective uses of digital storytelling as a } \\
\text { teaching and learning tool. In J. Flood, J. B. Heath, \& D. Lapp } \\
\text { (Eds.), Handbook of research on teaching literacy through the } \\
\text { communicative and visual arts (Volume 2). Lawrence Erbaum } \\
\text { Associates, NY. }\end{array}$ & 7 & 176 \\
\hline 11 & $\begin{array}{l}\text { Büyüköztürk, Ş., Kılıç-Çakmak, E., Akgün, Ö. E., Karadeniz, Ş. \& } \\
\text { Demirel, F. (2013). Scientific Research Methods. (14th edition). } \\
\text { Ankara: Pegem Akademi. }\end{array}$ & 7 & 11165 \\
\hline 12 & $\begin{array}{l}\text { Büyüköztürk, Ş. (2014). Handbook for data analysis in social } \\
\text { sciences (Extended 19th Edition). Ankara: Pegem Akademi. }\end{array}$ & 7 & 12468 \\
\hline 13 & $\begin{array}{l}\text { Porter, B. (2004). Digitales: The Art of Telling Digital Stories. USA: } \\
\text { Bernajean Porter Consulting. }\end{array}$ & 5 & 141 \\
\hline
\end{tabular}


When Table 18 is examined, the most cited books in doctoral dissertations are the publications called Digital story telling cookbook and traveling companion (17), Digital Storytelling in The Classroom: New Media Pathways to Literacy, Learning and Creativity (16), Digital storytelling: Capturing lives, creating community (13), Qualitative research methods in social sciences (13), and Digital storytelling: Guide for educators (11). Of the 13 books cited 5 times and above, 6 are directly related to digital storytelling.

Table 19 presents the most cited researchers in doctoral dissertations.

Table 19: Most frequently cited authors in doctoral dissertations

\begin{tabular}{clcc}
\hline Rank & Author & Number of Citations & GS Citation \\
\hline 1 & Bernard R. Robin & 122 & 5386 \\
2 & Bülent Doğan & 48 & 393 \\
3 & John W. Creswell & 43 & - \\
4 & Sara Kajder & 38 & 1653 \\
5 & Joe Lambert & 30 & - \\
6 & David S. Jakes & 27 & - \\
7 & Jason Ohler & 26 & - \\
8 & SenerBüyüköztürk & 25 & 42962 \\
9 & PelinYüksel & 25 & 814 \\
10 & Ya-Tİng C. Yang & 24 & - \\
11 & Wan-Chi I. Wu & 24 & - \\
12 & Glen Bull & 23 & - \\
13 & Najat Smeda & 22 & - \\
\hline
\end{tabular}

When Table 19 is examined, the top five most cited authors in doctoral dissertations are Bernard R. Robin (128), Bülent Doğan (48), John W. Creswell (43), Sara Kajder (43) ,and Joe Lambert (49). Four of the top five authors have been carrying out studies on digital storytelling. John W. Creswell, on the other hand, is famous for his scientific research method books that he presented to the literature. It is possible to say that the studies he carried out in this field were cited in the theses examined.

\section{Discussion and Conclusion}

In this research, digital stories prepared in the field of education at universities in Turkey were examined in terms of content and citation. In the content analysis section, the overall characteristics of the theses (year and type, the universities in which they were produced, the titles of the supervisors, the field in which the thesis was prepared, the most frequently used keywords) and features of methodology (methods used, models, sample types, data collection tools, types of data analysis, digital story creation tools, target population of digital story application) were discussed. In the section of citation analysis, the distribution of the sources cited in the theses according to their types, the most cited journals, the most cited books, and the most cited researchers were examined. With content analysis, holistic aspects of the studies in the field were tried to be presented. With the citation analysis, the aim was to create a core collection of sources and authors 
in the field of digital stories. Thus, it will be possible to present a collection of basic knowledge with the findings of this study to the researchers who want to work on the subject.

With the scanning carried out, it was found that the first postgraduate theses on digital stories in the field of education in Turkey were started to be prepared in 2011. Considering that digital storytelling dated back to the 1990s, it can be stated that the studies on the subject started a little late in Turkey. Until 2020, there has been a steady increase in the number of theses on digital stories. Liu, Wu, and Yin (2017) also state that research on digital stories has been increasing substantially since 2010. Similar results are also found in different studies (Demirbaş \& Şahin, 2020; Talan, 2019).

Theses related to the digital stories were mostly prepared at Gazi University and Atatürk University. It can be stated that these universities are among the leading institutions in the field of education in Turkey. In addition, it was determined that the titles of thesis supervisors are mostly associate professor and professor. "Academic titles often reveal clues about the scholar's scientific identity" (Şeref \& Karagöz, 2020, p. 1177). It is revealed that because the researchers with the title of associate professor and professor hold the thesis supervisor status, these theses are prepared under the supervision of researchers with advanced academic experience.

The postgraduate theses examined were mainly prepared in the fields of Elementary Education, Computer and Instructional Technologies Education, Science Education, and Turkish Education. When these fields are examined, it is revealed that there are both verbal and numerical fields. Accordingly, it can be stated that digital stories can be used as a teaching tool because they attract attention in different disciplines. From this point of view, digital stories have a quality that makes interdisciplinary information exchange possible. It was determined that digital stories are generally used in the fields of Science, Turkish and Foreign Language in Talan's (2019) study, they were used in the field of Native Language /Turkish Education in the study of Şimşek, Koçak-Usluel, Çıral1Sarica \& Tekeli (2018) and they were mostly preferred in the fields of Social Studies, Science and Turkish in the study of Ersözlü\&Yalçınalp (2020). Wu and Chen (2020) reported that digital stories were most frequently used in the field of language/language and literature. The theses on digital story were mostly carried out in the field of elementary education in this study. However, it should be noted that the theses written are carried out within the scope of primary literacy/Turkish education, a sub-branch of elementary education. In addition, it is found that a remarkable number of theses have been prepared in the field of English Education.

When the theses are examined in terms of method, it is found that mixed and quantitative approaches are adopted most frequently. Various mixed models were preferred in mixed methods studies. In quantitative studies, the studies were carried out only according to the experimental models. In the study carried out by Şimşek et al. (2018), it was stated that mostly qualitative and mixed methods were usedin the studies examined and the experimental model was preferred more frequently as a model. In the study of Ersözlü \& Yalçınalp (2020), it was stated that besides the use of more qualitative 
methods, the studies carried out via experimental model are also abundant. In the study of Demirbaş \& Şahin (2020), it was determined that quantitative methods were used in the theses on digital stories and qualitative methods were used in the articles. In the systematic review studies conducted by $\mathrm{Wu}$ and Chen (2020) and Talan (2019), it was determined that mixed methods were preferred more as in this study. Mixed methods research helps to carry out more in-depth academic studies. In this respect, using mixed methods in the theses can be considered as a positive situation. The samples of the examined theses were mostly selected from K-12 students. When we look at various studies, it is revealed that K-12 students are mostly chosen as samples in research on digital stories (Demirtaş \& Şahin, 2020; Şeref, 2020a; Şimşek, et al., 2018; Talan, 2019). Scale, achievement test and interview form were the most used data collection tools in the theses. The frequent preference of scales can be explained with the fact that they discuss the phenomenon in affective domains and examine understanding of the impact of digital stories on these domains. The reason for the preference of achievement tests intensely could be that they are the tools that allow pre- and post-tests of experimental models in research. In Demirtaş \& Şahin's (2020) study, it was stated that documents and interviews were the most used data collection tools. In the study conducted by Talan (2019), it was reported that the interview forms were used the most and then they were followed by the scales. Another feature of methodology used in data analysis preferences included mostly t-test, content analysis, Mann Whitney $U$, and Wilcoxon tests, respectively. T-test, Mann Whitney $\mathrm{U}$, and Wilcoxon tests are used to compare the differences between the means between a single group or two groups. The frequent use of these tests can be explained by the execution of experimental procedures in experimental and mixed research. Content analysis may also have been used to analyze interview forms that are frequently used in data collection tools. In Demirbaş\&Şahin's (2020) study, it was determined that t-test, Mann Whitney U test, and content analysis were the most used in theses related to digital stories, while content analysis, t-test, and descriptive analysis were used in articles.

It was determined that Photo Story 3 computer program was the most used tool to create digital stories in postgraduate theses. In the second place, the Windows Movie Maker program was preferred. In addition, digital story creation tools and digital stories were mostly carried out on secondary school and primary school students. In the study of Ersözlü \& Yalçınalp (2020), it was stated that mostly Photo Story 3 and Windows Movie Maker computer programs were used as digital story creation tools, and secondary school students were chosen as participants. It can be stated that these programs are preferred because they are freely accessible and user-friendly.

The most frequently used keywords in the theses are "digital story/storytelling narration/design, academic achievement, and attitude". The use of keywords provides various clues about the subject studied by reflecting the content of the study and is useful in identifying studies related to the subject studied (Tatar \& Tatar, 2008; Sevim, \& Şeref, 2015; Şeref, 2019). In this research, keywords related to digital story were encountered in all studies. After that comes academic achievement and attitude. In a more clear way, it 
can be interpreted that academic achievement and attitude are examined in studies on digital stories.

According to the citation analysis done in the second stage of the study, it was found that the most frequently cited sources in the postgraduate these were the articles and then the books in the second place. As in this research, it was determined that the most frequently used sources were the articles in the study in which the citation analysis of the articles on educational sciences and teacher training in Turkey was conducted (Karadağ et al., 2017). In addition, books, which are the main source of information in social sciences, were determined as the second type of source cited in the research. In the literature, it is stated that books are the majority type of sources which are cited in the theses related to social sciences (Özenç-Uçak \& Al, 2008).

The most cited journal in both master's theses and doctoral dissertations was Computers $\mathcal{E}$ Education. The second most frequently cited journal is Educational Technology $\mathcal{E}$ Society. The journal called Learning ELeading with Technology, which is not published today, takes the third place. The first two of these journals are indexed by the Web of Science Social Sciences Citation Index. Thus, it is revealed that the most frequently cited journals are reviewed by an eligible international index. The first three journals are foreign addressed publications. This situation indicates that the international literature is followed in the theses completed in Turkey.

When the book/book section that is most frequently cited in the theses is examined, it is found that the same works are ranked in the first two places in both master's theses and doctoral dissertations. The publication called Digital Storytelling Cookbook and Traveling Companion written by Joe Lambert takes the first place. The book is a reference work written on the preparation of digital stories. Joe Lambert, together with Dana Atchey and Nina Mullen, founded the San Francisco Digital Media Centre in 1994. This centre moved to Berkeley in 1998 and became the Centre for Digital Storytelling, and in 2015, this organization became Story Centre and has survived until today (Story Center, www.storycenter.org/history). Joe Lambert is currently the executive director of this organization. As you can see, Joe Lambert is a very important name in the history of digital storytelling. It can be considered as a normal situation that the most frequently cited book in the theses belongs to the researcher who is the founder of this field. Jason Ohler with his book Digital Storytelling in The Classroom: New Media Pathways to Literacy, Learning and Creativity takes the second place. This book is also a book prepared directly on digital stories. The author continues to work on topics such as technology in education, digital literacy, and curriculum development (www.jasonohlerideas.com/portfolio). Apart from the books directly related to digital storytelling, there are also books about scientific research methods among the most frequently cited books. These books which should be found in the theses in the field of education are used in the method section. In general, this is consistent with our knowledge that books on research methods knowledge play an active role after the reference books in educational research (Şeref \& Karagöz, 2019; Karadağ, 2017). 
Bernard R. Robin was the most frequently cited author in both master's theses and doctoral dissertations. Robin, a faculty member in the Master's Program in Learning, Design and Technology at the University of Houston College of Education, continues to work in the fields of instructional technology training for the professional development of teachers and education administrators; the design and development of communitybased websites; the educational use of digital photography, digital video and digital storytelling; and the use of technology to support education in health sciences (University of Houston, http://faculty.coe.uh.edu/brobin/homepage/). In 2004, the researcher pioneered the foundation of the Educational Uses of Digital Storytelling website to serve as a useful resource for educators and students interested in how digital storytelling can be integrated into various educational activities (Robin, 2020). Robin won the Multimedia Educational Resource for Learning and Online Teaching (MERLOT) Faculty Development Classics award for this website in 2009 (MERLOT, www.merlot.org/merlot/viewMaterial.htm?id=86124). In addition, the author, who is an intellectual pioneer in the field, has over 25 studies on digital story.

In this research, 68 theses accessed through the National Thesis Centre of the Council of Higher Education constitute the limitation of the study. The scope of the study can be expanded by including articles published in reputable databases such as Web of Science.

\section{Conflict of Interest Statement}

The author declares no conflicts of interest related to the study or preparation of the manuscript.

\section{About the Author}

Dr. Beytullah Karagöz is an Associate Professor Doctor at Tokat Gaziosmanpaşa University, Faculty of Education, Tokat, Turkey.

\section{References}

Akgün, M., \& Akgün, İ. H. (2020). The Effect of Digital Stories on Academic Achievement: A Meta-Analysis. Journal of Education and Learning, 9(6), 71-83. doi:10.5539/jel.v9n6p71

Barrett, H. (2006). Convergence of student-centered learning strategies. Technology and Teacher Education Annual, 1, 647-654.

Becker, D. A., \& Chiware, E. R. (2015). Citation analysis of masters' theses and doctoral dissertations: Balancing library collections with students' research information needs. The Journal of Academic Librarianship, 41(5), 613-620.

Bernard R. Robin (2008). Digital Storytelling: A Powerful Technology Tool for the 21st Century Classroom, Theory into Practice, 47:3, 220-228, DOI: 10.1080/00405840802153916 
Büyüköztürk, Ş., Kılıç-Çakmak, E., Akgün, Ö.E., Karadeniz, Ş., \& Demirel, F. (2010). Bilimselaraştırmayöntemleri(6.baskı). Ankara: Pegem Yayınları.

Castañeda, M. E. (2013). I am proud that I did it and it's a piece of me: Digital storytelling in the foreign language classroom. CALICO journal, 30(1), 44-62.

Center for Digital Storytelling (2004). Seven elements for digital storytelling. Retrieved from:

https://digitalstorytelling.coe.uh.edu/page.cfm?id=27\&cid=27\&sublinkid=31

Cushing, D. F., \& Love, E. W. (2013). Developing cultural responsiveness in environmental design students through digital storytelling and photo voice. Journal of Learning Design Cushing \& Love Special Issue: Design Education, 6(3), 63-75

Demirbaş, İ., \& Şahin, A. (2020). A Systemic Analysis of Research on Digital Storytelling in Turkey. International Journal of Progressive Education, 16(4), 45-65.

Ersözlü, U., \& Yalçınalp, S. (2020, Aralık). Türkiye'de 2016-2020 yıllarıarasındadijitalöyküaraştırmalarıüzerinesistematik inceleme. DILET2020 The 3rd International Conference on Distance Learning and Innovative Educational Technologies (ss. 242-257), 10-11 Aralık 2020, Ankara, Türkiye.

Garrety, C. M. (2008). Digital storytelling: An emerging tool for student and teacher learning (Doctoral dissertation, Iowa State University).

Gregori-Signes, C., \& Pennock-Speck, B. (2012). Digital storytelling as a genre of mediatized self-representations: An introduction. Digital Education Review, 22, 1-8.

Jakes, D. S., \& Brennan, J. (2005). Capturing stories, capturing lives: An introduction to digital storytelling. http://id3432.securedata.net/jakesonline/dst techforum.pdf

Karadă̆, E., Yalçın, M., Çiftçi, K., Danışman, Ş., Sölpük, N., Tosuntaş, Ş., \& Ay, Y. (2017). Türkiye' de eğitim bilimleri ve öğretmen yetiştirme alanındaki bilimsel yayınların atıf analizleri. Bilgi Dünyası, 18(1), 9-28.

Karagöz, B., \& Şeref, İ. (2020). Yazma becerisiyle ilgili makaleler üzerine bir inceleme: Web of Science veritabanında eğilimler. Ana Dili Ĕ̆itimiDergisi, 8(1), 67-86.

Kengerü, A. (2016). Bir ifade aracı olarak dijital öykü anlatımı. Abant Kültürel Araştırmalar Dergisi, 1(2), 33-45.

Liu, S., Wu, J., \& Yin, X. L. (2017). Visualization analysis of researches on digital storytelling based on mapping knowledge domain. Journal of Literature and Art Studies, 7(12), 1681-1690.

Lundby, K. (2008). Digital storytelling, mediatized stories: Self-representations in new media. New York: Peter Lang.

Miller, C. H. (2019). Digital storytelling: A creator's guide to interactive entertainment. Burlington, MA: FocalPress.

Moher, D., Liberati, A., Tetzlaff J., \& Altman, D. G. (2009). Preferred reporting items for systematic reviews and meta-analyses: the PRISMA statement. BMJ, 339: b2535 doi:10.1136/bmj.b2535

Özenç-Uçak, N. ve Al, U. (2008). Sosyal bilimler tezlerinin atıf özellikleri. Hacettepe Üniversitesi Edebiyat Fakültesi Dergisi, 25(2), 223-240. 
Özkaya, P. G. (2020). Dijital öykülerin Türkçe dil becerilerinin gelişimine etkisi: Bir meta analiz çalışması. Ana Dili Eğitimi Dergisi, 8(4), 1386-1405.

Robin, B. (2006, March). The educational uses of digital storytelling. In Society for Information Technology \& Teacher Education International Conference (pp. 709-716). Association for the Advancement of Computing in Education (AACE).

Robin, B. (2008). Digital storytelling: A powerful technology tool for the 21st century classroom. Theory into Practice, 47(3), 220-228. doi: 10.1080/00405840802153916

Robin, B. (2020). The Educational Uses of Digital Storytelling Website University of Houston College of Education http://digitalstorytelling.coe.uh.edu

Robin, B. R. (2016). The power of digital storytelling to support teaching and learning. Digital Education Review, (30), 17-29.

Robin, B., \& Pierson, M. (2005). A multilevel approach to using digital storytelling in the classroom. In Society for information technology $\mathcal{E}$ teacher education international conference (pp. 708-716). Association for the Advancement of Computing in Education (AACE).

Şeref, İ. (2019). Türkçe Öğretiminde Şiir Üzerine Yapılan Lisansüstü Tezlerin Değerlendirilmesi. Igdir University Journal of Social Sciences, (20), 335-349.

Şeref, İ. (2020a). Etkinliklere Dayalı Ontolojik Metin Analizi Yönteminin Yedinci Sınıf Öğrencilerinin Şiir Çözümleme Başarılarına Etkisi. Kastamonu Eğitim Dergisi, 28(1), 267-285.

Seref, I. (2020b). The Investigation into the Dependency Level of Turkish Language Teachers on Coursebooks. Online Submission, 7(5), 163-174.

Şeref, İ., \& Karagöz, B. (2020). Citation analysis of graduate theses on teaching of Turkish as a foreign language (1988-2019). Çukurova Üniversitesi Eğitim Fakültesi Dergisi, 49(2), 1145-1183.

Sevim, O. \& Şeref, İ. (2015). Türkçe öğretmen adaylarının okuma eğitimi dersiyle ilgili görüş ve önerileri. EKEV Akademi Dergisi, 61, 365-378.

Şimşek, B., Usluel, Y. K., Sarıca, H. Ç., \& Tekeli, P. (2018). Türkiye'de eğitsel bağlamda dijital hikâye anlatımı konusuna eleştirel bir yaklaşım. Eğitim Teknolojisi Kuram ve Uygulama, 8(1), 158-186.

Sylvester, R., \& Greenidge, W. L. (2009). Digital storytelling: Extending the potential for struggling writers. The reading teacher, 63(4), 284-295.

Talan, T. (2019). Dijital öyküleme yöntemi ile ilgili yapılan çalışmalara sistematik bir bakış. Uluslararası Öğretim Teknolojileri ve Öğretmen Eğitimi Sempozyumu (ss. 692709), Antalya, Türkiye.

Tatar, E., \& Tatar, E. (2008). Fen bilimleri ve matematik eğitimi araştırmalarının analizi I: Anahtarkelimeler. İnönü Üniversitesi Ĕ̆itim Fakültesi Dergisi, 9(16), 89-103.

Turan, S., Karadağ, E., Bektaş, F., \& Yalçın, M. (2014). Türkiye'de eğitim yönetiminde bilgi üretimi: Kuram ve Uygulamada Eğitim Yönetimi Dergisi 2003-2013 yayınlarının incelenmesi. Kuram ve Uygulamada Eğitim Yönetimi, 20(1), 93-119. doi: 10.14527/kuey.2014.005 
Wu, J., \& Chen, D. T. V. (2020). A systematic review of educational digital storytelling. Computers $\mathcal{E}$ Education, 147, 103786.

Yıldırım, A., \& Şimşek, H. (2011). Sosyal bilimlerde nitel araştırma yöntemleri. Ankara: Seçkin Yayıncılık.

Yuksel, P., Robin, B., \& McNeil, S. (2011, March). Educational uses of digital storytelling all around the world. In Society for Information Technology $\mathcal{E}$ Teacher Education International Conference (pp. 1264-1271). Association for the Advancement of Computing in Education (AACE).

Creative Commons licensing terms

Author(s) will retain the copyright of their published articles agreeing that a Creative Commons Attribution 4.0 International License (CC BY 4.0) terms will be applied to their work. Under the terms of this license, no permission is required from the author(s) or publisher for members of the community to copy, distribute, transmit or adapt the article content, providing a proper, prominent and unambiguous attribution to the authors in a manner that makes clear that the materials are being reused under permission of a Creative Commons License. Views, opinions and conclusions expressed in this research article are views, opinions and conclusions of the author(s). Open Access Publishing Group and European Journal of Education Studies shall not be responsible or answerable for any loss, damage or liability caused in relation to/arising out of conflicts of interest, copyright violations and inappropriate or inaccurate use of any kind content related or integrated into the research work. All the published works are meeting the Open Access Publishing requirements and can be freely accessed, shared, modified, distributed and used in educational, commercial and non-commercial purposes under a Creative Commons Attribution 4.0 International License (CC BY 4.0). 